\title{
Karakterisasi, Pengaruh Sumber Nitrogen dan Karbon terhadap Produktivitas Enzim Lipase Rhizopus microsporus var oligosporus UICC 550
}

\author{
Partial Characterization, Effect of Nitrogen and Carbon Sources on Production of Lipase \\ of Rhizopus microsporus var oligosporus UICC 550
}

\author{
Wibowo Mangunwardoyo*, Yuyun Lusini, Indrawati Gandjar \\ Departemen Biologi, Fakultas Matematik dan Ilmu Penegetahuan Alam, Universitas Indonesia, Depok, 16424 \\ E-mail: w_mangunwardoyo@hotmail.com *Penulis untuk korespondensi
}

\begin{abstract}
Effect of nitrogen and carbon source on the production of extracellular lipase by $\boldsymbol{R}$. microsporus var. oligosporus UICC 550 was studied. The enzyme activity was also characterized in terms of temperature, $\mathrm{pH}$, stability at room temperature, and effect of divalent ion. The amount of $2.5 \%(\mathrm{w} / \mathrm{v})$ of olive oil as carbon sources and $5 \%(\mathrm{w} / \mathrm{v})$ peptone as nitrogen sources were the optimum for production of lipase enzyme. Partial purifications using ammonium sulfate followed by dialysis showed that at $\mathbf{p H}$ 6.5 and temperature $35^{\circ} \mathrm{C}$ was the optimum condition, respectively. The stability (remaining up to $80 \%$ of the optimum enzyme) was recorded at pH 6.5 after 24 hours incubation at room temperature. The optimum activity remained $40 \%$ of the after one hour incubation at $35^{\circ} \mathrm{C}$. Divalent ions concentration at $1 \mathrm{mM}, \mathrm{Zn}^{2+}, \mathrm{Cu}^{2+}, \mathrm{Mg}^{2+}$ and $\mathrm{Fe}^{2+}$ inhibited the lipolytic activity.
\end{abstract}

Key words: amonium sulphate, olive oil, peptone, Rhizopus microsporus var oligosporus UICC 550, pH and temperature optimum

Diterima: 23 Juni 2008, disetujui: 30 April 2009

\section{Pendahuluan}

Lipase mikroba merupakan lipase ekstraselular yang diekskresikan melalui membran sel ke dalam medium. Optimasi kondisi fermentasi mikroba penghasil lipase sangat penting karena dapat mempengaruhi produksi enzim (Taipa et al., 1992). Produksi lipase tergantung pada beberapa faktor lingkungan seperti suhu, waktu inkubasi, umur dan jumlah inokulum, $\mathrm{pH}$ medium, sumber karbon, nitrogen, dan lipid, konsentrasi garamgaram anorganik, dan ketersediaan oksigen (Yoshida et al., 1968; Davranov dan Khalameizer, 1997; Sarkar et al., 1998).

Pokorny et al., (1994), menyatakan bahwa biosintesis lipase dapat berlangsung tanpa substrat lipid dan dapat ditingkatkan dengan penambahan inducer dalam medium. Aspergillus niger mengalami peningkatan produksi lipase apabila dalam medium kultur ditambahkan substrat lipid (Macris et al., 1996). Penambahan minyak zaitun sebagai substrat lipid pada medium kultur Candida rugosa juga meningkatkan produksi lipase. Peranan faktor-faktor lain seperti sumber karbon, nitrogen dan mineral tidak dapat diabaikan (Benjamin dan Pandey, 1996). Oleh karena itu, optimasi medium mikroba merupakan tahapan penting untuk mendapatkan produksi enzim maksimal (Sharma et al., 2001).

Aplikasi lipase dalam bidang biomedik dan industri farmasi memerlukan lipase dengan tingkat kemurnian tinggi dan harus dikenal sifat-sifat spesifiknya seperti, kekhususan substrat, $\mathrm{pH}$ dan suhu optimum, pengaruh penambahan ion-ion logam dan lain-lain. Ionion logam umumnya dapat membantu kerja enzim. Ion-ion logam alkali $\left(\mathrm{Na}^{+}, \mathrm{K}^{+}\right)$dan 
logam-logam transisi $\left(\mathrm{Mg}^{2+,} \mathrm{Cu}^{2+}, \mathrm{Zn}^{2+}, \mathrm{Mn}^{2+}\right.$, $\mathrm{Fe}^{2+}, \mathrm{Fe}^{3+}$ dan lain-lain) dapat membantu kerja enzim di antaranya dengan membentuk ikatan kovalen dengan substrat, sehingga substrat semakin mudah terikat pada sisi aktif enzim (Boyer, 2002). Karakterisasi biokimiawi lipase adalah sangat penting untuk menentukan potensi aplikasinya (Benjamin dan Pandey, 2001).

Dari penelitian ini dapat diketahui (1) kondisi fermentasi terbaik $R$. microsporus var. oligosporus UICC 550 untuk memproduksi enzim lipolitik; (2) karakter enzim yang telah dipurifikasi sebagian pada suhu dan $\mathrm{pH}$ optimum, serta kestabilan enzim pada suhu, $\mathrm{pH}$, dan penambahan ion divalen.

\section{Metode Penelitian}

\section{Mikroba}

Rhizopus microsporus var. oligosporus UICC 550 koleksi University of Indonesia Collection Culture (UICC).

\section{Medium}

Medium pemeliharaan $R$. microsporus var. oligosporus UICC 550 pada Potato Dextro Agar (PDA). Medium basal dan fermentasi menurut (Samad et al., 1990) dimodifikasi oleh (Ellibol dan Ozer, 2002). Minyak zaitun (Bertoli) diemulsifikasikan berdasarkan metode Kulkarni (2002).

\section{Penentuan aktivitas lipolitik}

Aktivitas lipolitik ditentukan dengan cara titrasi menurut (Samad et al., 1990). Substrat minyak zaitun diemulsikan, dengan menambahkan $1 \%(\mathrm{~g} / \mathrm{v})$ PVA ke dalam minyak zaitun $(50 \% \quad \mathrm{v} / \mathrm{v})$ kemudian ditambahkan sedikit demi sedikit bufer fosfat $\mathrm{pH}$ 7,5 (50\% $\mathrm{v} / \mathrm{v})$ sambil terus dikocok. Emulsi dihomogenkan dengan shaker $150 \mathrm{rpm}$, selama minimal satu jam. Substrat $2,5 \mathrm{ml}$ yang telah diemulsikan ditambahkan $1 \mathrm{ml}$ filtrat enzim dan $20 \mu \mathrm{l} \mathrm{CaCl}_{2}$ 0,02 M. Campuran tersebut diinkubasikan dalam waterbath-shaker, pada suhu $35^{\circ} \mathrm{C}$ selama 30 menit, dengan kecepatan pengocokan $120 \mathrm{rpm}$. Sebanyak $3,5 \mathrm{ml}$ campuran etanol dan aseton p.a (1:1) ditambahkan pada substrat untuk menghentikan kerja enzim. Selanjutnya ditambahkan dua tetes larutan fenolftalein $1 \%$ dan dititrasi dengan larutan $\mathrm{NaOH}$ 0,05 M yang telah distandarisasi. Aktivitas lipolitik dinyatakan dengan banyaknya $\mathrm{NaOH} 0,05 \mathrm{M}$ yang diperlukan untuk menetralkan asam lemak yang dibebaskan (Samad et al., 1990). Satu unit aktivitas lipase didefinisikan sebagai $\mu \mathrm{mol}$ asam lemak yang dibebaskan per menit pada suhu $35^{\circ} \mathrm{C}$.

\section{Optimasi Produk Enzim Lipolitik}

Pengaruh konsentrasi substrat minyak zaitun

Sebanyak 0,2 $\mathrm{ml}$ suspensi spora $(1,4-$ $2,88 \times 10^{6} \mathrm{spora} / \mathrm{ml}$ ) ditambahkan ke dalam Erlenmeyer $100 \mathrm{ml}$, berisi $20 \mathrm{ml}$ medium basal. Emulsi minyak zaitun 20\% ditambahkan dalam medium basal sebagai substrat lipid sehingga konsentrasi akhir adalah 1,$0 ; 1,5 ; 2,0 ; 2,5$ dan $3 \%$ (v/v). Medium diinkubasikan dalam shaker incubator, pada suhu ruang $\left(27-30^{\circ} \mathrm{C}\right)$, kecepatan agitasi $110 \mathrm{rpm}$ dan diinkubasikan selama 48 jam. Hasil fermentasi disaring dengan kertas Whatman nomor 1. Aktivitas lipolitik ditentukan berdasarkan metode titrasi (Samad et al., 1990) dan biomassa dikeringkan dalam oven $80^{\circ} \mathrm{C}$ hingga konstan. Perhitungan berat kering biomassa ditentukan menurut (Nahas, 1988).

\section{Pengaruh konsentrasi pepton}

Medium basal dengan konsentrasi pepton $2,3,4,5,6$, dan $7 \%$ (b/v). Sebanyak 0,2 $\mathrm{ml}$ suspensi spora $\left(1,4-2,88 \times 10^{6} \mathrm{spora} / \mathrm{ml}\right)$ dari inokulum umur lima hari, ditambahkan ke dalam Erlenmeyer $100 \mathrm{ml}$ yang berisi $20 \mathrm{ml}$ medium basal dengan konsentrasi pepton yang berbeda. Substrat lipid, berupa minyak zaitun yang telah diemulsikan ditambahkan dalam medium hingga konsentrasi akhir substrat lipid dalam medium 2,5\% (v/v). Selanjutnya diinkubasikan dalam shaker incubator, pada suhu ruang $\left(27-30^{\circ} \mathrm{C}\right)$, kecepatan agitasi 110 rpm selama 48 jam. Setiap perlakuan dilakukan tiga ulangan. Hasil fermentasi disaring dengan kertas Whatman nomor 1. Aktivitas lipolitik ditentukan berdasarkan metode titrasi (Samad et al., 1990) dan biomassa dikeringkan dalam oven $80^{\circ} \mathrm{C}$ hingga konstan. Perhitungan berat kering biomassa ditentukan menurut (Nahas, 1988). 


\section{Pembuatan kurva produksi enzim lipolitik} dan berat biomassa

Sebanyak 0,2 ml suspensi spora $(1,4-2,88$ x $10^{6}$ spora/ml) diinokulasikan ke dalam Erlenmeyer $100 \mathrm{ml}$, yang berisi $20 \mathrm{ml}$ medium basal. Konsentrasi pepton 5\% dan konsentrasi minyak zaitun 2,5\% (v/v). Erlenmeyer yang berisi biakan diinkubasikan di dalam shaker incubator, pada suhu ruang $\left(27-30^{\circ} \mathrm{C}\right)$, kecepatan agitasi $110 \mathrm{rpm}$.

Sampel diukur aktivitas lipolitiknya dan berat kering biomassanya pada jam ke: $0,4,8$, 12, 16, 20, 40, 46, 50, 56, 62, dan 72 .

\section{Purifikasi Parsial Enzim}

\section{Presipitasi ammonium sulfat}

Medium fermentasi setelah jam ke 56 inkubasi disaring dengan kertas Whatman No. 1. Selanjutnya filtrat $(300 \mathrm{ml})$ diendapkan dengan menambahkan 141,6 g ammonium sulfat $(70 \%)$, berdasarkan metode Scopes (1988).

\section{Dialisis}

Filtrat yang telah diendapkan selama 24 jam, disentrifugasi $\left(4^{\circ} \mathrm{C}\right)$ dengan kecepatan $20.000 \mathrm{rpm}$ selama 10 menit. Endapan hasil sentrifugasi diresuspensi dengan sesedikit mungkin bufer fosfat $\mathrm{pH}$ 7,5. Semua hasil resuspensi dimasukkan ke dalam kantung dialisis kemudian direndam dalam bufer fosfat pH 7,5 selama 24 jam dengan dua kali penggantian larutan bufer. Dialisis dilakukan dalam ruangan bersuhu $4^{\circ} \mathrm{C}$ atau dalam lemari es selama 48 jam.

\section{Karakterisasi enzim}

Penentuan karakterisasi enzim dilakukan berdasarkan cara yang dilakukan oleh Koblitz dan Pastore (2006).

\section{Pengaruh pH dan suhu pada aktivitas dan kestabilan enzim}

Pengukuran $\mathrm{pH}$ optimum aktivitas lipolitik menggunakan beberapa variasi $\mathrm{pH}$ yaitu 4,$0 ; 4,6 ; 5,4 ; 6,5 ; 7,5 ; 8,0 ; 8,4$ dan 9,5 . pada suhu $35^{\circ} \mathrm{C}$. Kestabilan enzim pada beberapa $\mathrm{pH}$ diuji dengan penentuan aktivitas lipolitik sisa pada $\mathrm{pH}$ optimum setelah larutan enzim diinkubasikan selama 24 jam pada suhu ruang $\left(27-30^{\circ} \mathrm{C}\right)$ dengan variasi $\mathrm{pH} 4,6 ; 5,4$; 6,$5 ; 7,5 ; 8,4$ dan 9,5 . Untuk mencapai $\mathrm{pH}$ yang diinginkan, larutan enzim di tambahkan larutan bufer yang sesuai. Bufer yang digunakan untuk variasi $\mathrm{pH}$ larutan enzim, dibuat berdasarkan metode Colowick dan Kaplan (1955).

Pengukuran suhu optimum ditentukan dengan mengukur aktivitas lipolitik pada beberapa variasi suhu $30 ; 35 ; 40 ; 45 ; 50 ; 55$; $60^{\circ} \mathrm{C}$, pada $\mathrm{pH}$ optimum $(\mathrm{pH} 6,5)$. Kestabilan enzim pada berbagai suhu diuji dengan menentukan sisa aktivitas lipolitik setelah larutan enzim diinkubasikan dalam tiga suhu 30,35 , dan $40^{\circ} \mathrm{C}$ selama 1 jam.

\section{Pengaruh ion-ion divalen}

Sebanyak $1 \mathrm{ml}$ enzim ditambahkan $50 \mu \mathrm{l}$ larutan ion-ion logam divalen $\mathrm{Zn}^{2+}, \mathrm{Cu}^{2+}, \mathrm{Mg}^{2+}$ dan $\mathrm{Fe}^{2+} 0.02 \mathrm{M}$, sehingga konsentrasi akhir ion-ion logam dalam larutan enzim adalah 1 $\mathrm{mmol} / \mathrm{L}$, enzim diinkubasikan pada suhu ruang $\left(27-30^{\circ} \mathrm{C}\right)$ selama satu jam, kemudian ditentukan aktivitas lipolitik.

\section{Hasil dan Pembahasan}

\section{Optimasi Produksi Enzim}

\section{Pengaruh konsentrasi minyak zaitun}

Aktivitas lipolitik $R$. microsporus var. oligosporus UICC 550 semakin meningkat dengan bertambahnya konsentrasi minyak zaitun hingga konsentrasi substrat lipid mencapai $2,5 \%$ v/v $(2,72 \mathrm{U} / \mathrm{ml})$. Aktivitas lipolitik kemudian menurun $(1,88 \mathrm{U} / \mathrm{ml})$ pada konsentrasi minyak zaitun yang lebih besar (3\%) (Gambar 1). Pengaruh penambahan minyak zaitun terhadap penambahan biomassa berjalan seiring, dalam setiap penambahan konsentrasi minyak zaitun berat biomassa juga cenderung bertambah. Substrat lipid pada awalnya menginduksi peningkatan aktivitas lipolitik $R$. microsporus var. oligosporus UICC 550 , tetapi efek induksinya terbatas pada konsentrasi tertentu yaitu 2,5\%. Adanya induksi ini juga dilaporkan pada aktivitas lipolitik Candida rugosa (Laksmi et al., 1999) meningkat seiring dengan bertambahnya konsentrasi minyak kelapa hingga mencapai konsentrasi $10 \%$ (v/v) dan aktivitas lipolitiknya mengalami penurunan pada konsentrasi minyak 
lebih tinggi. Demikian juga dengan aktivitas lipolitik pada Mucor hiemalis (Akhtar, 1980).

\section{Pengaruh konsentrasi pepton}

Konsentrasi pepton berpengaruh pada produksi lipase. Produksi lipase terbaik diperoleh pada konsentrasi pepton $5 \%(\mathrm{~g} / \mathrm{v})$ (Gambar 2). Pepton merupakan sumber nitrogen organik yang dapat langsung digunakan oleh mikroba. Pepton $(5 \% \mathrm{~g} / \mathrm{v})$ memberikan pengaruh yang baik terhadap produksi lipase Aspergillus niger dibandingkan ammoniumnitrat $(0,1 \% \mathrm{~g} / \mathrm{v})$ jika tidak ada penambahan kalium fosfat $(0,1 \% \mathrm{~g} / \mathrm{v})$. Akan tetapi penambahan ammonium nitrat bersama kalium fosfat berpengaruh lebih baik daripada pepton terhadap produksi lipase A. niger (Pokorny et al., 1994). Samad et al., (1990) menguji beberapa sumber nitrogen pada $R$. chinensis dan pepton 5\% merupakan sumber nitrogen yang terbaik. Aspergillus sp. menunjukkan tingkat aktivitas lipolitik yang juga baik dalam medium pepton $1 \%$ dengan penambahan minyak zaitun $1 \%$ (Cihangir dan Sarikaya, 2004).

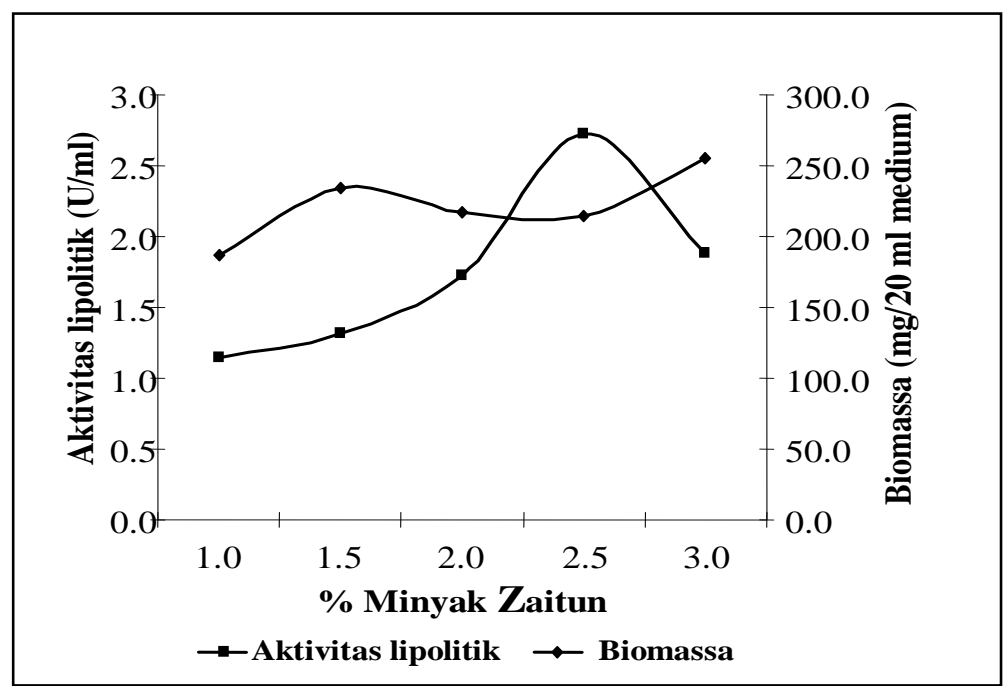

Gambar 1. Aktivitas lipolitik dan biomassa $R$. microsporus var. oligosporus UICC 550 dengan variasi konsentrasi minyak zaitun (\%), pada waktu inkubasi 48 jam.

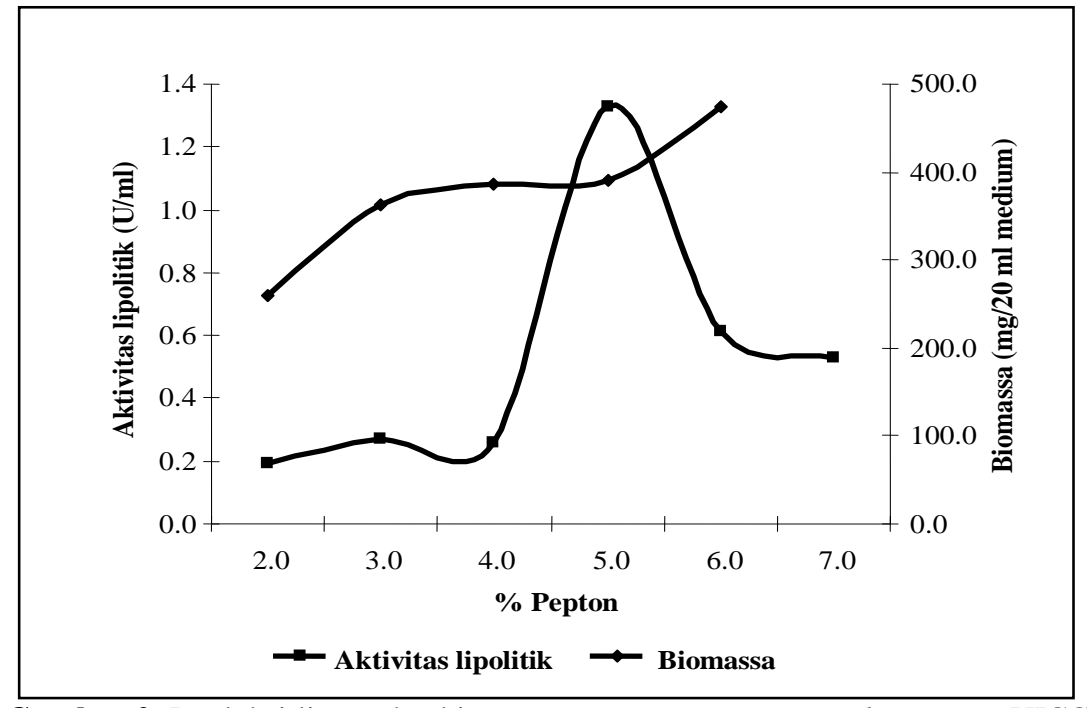

Gambar 2. Produksi lipase dan biomassa $R$. microsporus var. oligosporus UICC 550 dengan variasi konsentrasi pepton (\%) pada waktu inkubasi 48 jam. 


\section{Kurva produksi enzim lipolitik dan biomassa}

Gambar 3 menunjukkan produksi enzim lipase (biomassa dan perubahan $\mathrm{pH}$ ). Kurva produksi lipase memiliki dua puncak, yaitu pada jam ke $20(1.66 \mathrm{U} / \mathrm{ml})$ dan jam ke $56(2$, $99 \mathrm{U} / \mathrm{ml})$. Terbentuknya dua puncak produksi lipase tersebut, kemungkinan disebabkan oleh dua hal. Kemungkinan pertama adalah, aktivitas lipolitik pada jam ke 20 (fase akhir eksponensial), merupakan enzim ektraselular. Diperkirakan pada saat itu sumber $\mathrm{C}$ yang berasal dari glukosa sudah habis dan sel-sel mulai mensekresikan enzim lipolitik untuk memecah substrat lipid untuk sumber $C$ lainnya. Produksi lipase pada puncak kedua, yaitu pada jam ke 56 diperkirakan merupakan gabungan enzim lipase intraselular dan ekstraselular. Lipase intraselular diduga bergabung dengan lipase ekstraselular yang dibebaskan dalam medium pada akhir fase pertumbuhan (Druet et al., 1992). Hal tersebut didukung oleh pertumbuhan biomassa yang cenderung konstan. Kemungkinan kedua adalah tertundanya penggunaan asam oleat (dari minyak zaitun) karena penggunaan gliserol yang dilakukan terlebih dahulu. Gliserol yang dihasilkan dari hasil hidrolisis minyak zaitun (trigliserida) oleh lipase konstitutif menjadi represor penggunaan asam lemak oleh mikroba. Kemungkinan tersebut berdasarkan penelitian yang dilakukan oleh Del Rio et al., (1990) terhadap Candida rugosa, yang menjelaskan bahwa penggunaan minyak zaitun terjadi dalam dua tahap yaitu penggunaan gliserol tanpa memproduksi lipase (hanya lipase konstitusi). Setelah gliserol habis dikonsumsi oleh sel-sel, maka aktivitas lipase akan meningkat untuk menghidrolisis asam lemak oleat. Selama gliserol masih ada dalam medium asam-asam lemak tidak akan dikonsumsi oleh Candida rugosa, adanya gliserol dapat menekan (repression) penggunaan asam lemak.

Kemungkinan penyebab peningkatan aktivitas lipase pada fase stasioner juga dijelaskan oleh Pereira-Meirelles et al., (2000) yang melaporkan bahwa produksi lipase diawal pertumbuhan adalah lipase cell-bound, sehingga hanya lipase dalam tingkat basal yang akan terdeteksi dalam medium. Lipase ekstraselular mulai disekresikan ke dalam medium ketika sekitar 50\% dari sumber karbon (minyak zaitun atau glukosa) telah dikonsumsi dan lipase akan mencapai konsentrasi maksimum pada akhir fase stasioner.

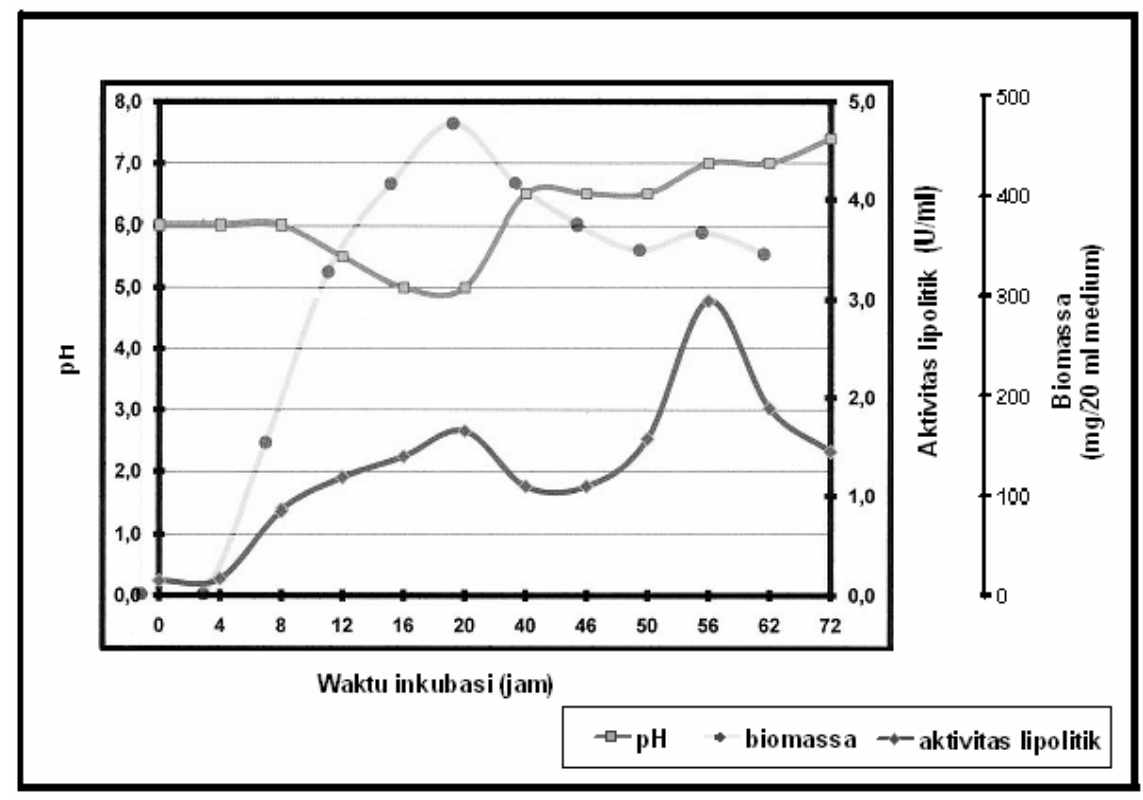

Gambar 3. Kurva produksi enzim lipase, biomassa, dan perubahan $\mathrm{pH} R$. microsporus var. oligosporus UICC 550 inkubasi selama 72 jam. 


\section{Purifikasi parsial enzim lipolitik}

Fraksi pertama hasil fermentasi aktivitasnya $0,46 \mathrm{U} / \mathrm{ml}$. Setelah pengendapan ammonium sulfat $0-70 \%$ yaitu fraksi kedua, aktivitas enzim lipolitik meningkat 17 kali, menjadi 6,24 U/ml. Fraksi ke tiga menunjukkan sedikit kenaikan yaitu menjadi $7,05 \mathrm{U} / \mathrm{ml}$ atau sekitar 28 kali dari aktivitas crude enzyme. Koblitz dan Pastore (2006) menggunakan ammonium sulfat $70 \%$ pada pemurnian enzim lipolitik $R$. microsporus. Rhizopus niveus memiliki aktivitas lipolitik yang tinggi ketika crude enzyme-nya dipresipitasi dengan ammonium sulfat 40-60\% (Kemarsha et al., 1998), sedangkan crude enzyme produksi $R$. oryzae dipresipitasi dengan penambahan ammonium sulfat $35-70 \%$ (Hiol et al., 2000). Iwai dan Tsujisaka (1974) menggunakan penambahan ammonium sulfat $70 \%$ pada crude enzyme $R$. delemar sebagai tahapan awal purifikasi.

\section{Karakterisasi Enzim}

\section{Pengaruh pH terhadap aktivitas dan stabilitas enzim}

Aktivitas lipolitik maksimum dicapai pada $\mathrm{pH} 6,5$ dalam bufer fosfat dan suhu $35^{\circ} \mathrm{C}$. Aktivitas enzim menurun pada $\mathrm{pH}$ asam atau basa (Gambar 4). Lipase yang diisolasi dari $R$. chinesis, memiliki pH optimum 5,5 (Yasuda et al., 1999). Rhizopus sp. memproduksi lipase dengan dua $\mathrm{pH}$ optimum yaitu 5,5 dan 7,5 (Koblitz dan Pastore, 2006).

Enzim yang diinkubasi pada suhu ruang selama 24 jam pada $\mathrm{pH}$ 6,5, menunjukkan penurunan aktivitas lipolitik sekitar 20\% dari aktivitas maksimum (Gambar 5), sedangkan pada $\mathrm{pH}$ lain penurunan aktivitas lipolitik sekitar $60 \%$. Penurunan aktivitas enzim lipolitik dapat disebabkan oleh efek denaturasi atau dapat juga disebabkan oleh kerja enzim protease (Maia et al., 1999).

\section{Pengaruh suhu terhadap aktivitas dan stabilitas}

Kapang $R$. microsporus var. oligosporus UICC 550 memiliki suhu optimum sebesar $35^{\circ} \mathrm{C}$ (Gambar 6). Pengukuran aktivitas lipolitik dilakukan pada $\mathrm{pH}$ optimum, yaitu 6,5. Suhu optimum diperoleh pada saat enzim menunjukkan aktivitas lipolitik maksimal. Pada suhu di atas suhu optimum aktivitas enzim mengalami penurunan.

Uji kestabilan enzim pada berbagai suhu (Gambar 7). Aktivitas lipolitik menurun sekitar $60 \%$ dari aktivitas maksimum pada suhu optimum $\left(35^{\circ} \mathrm{C}\right)$, sedangkan pada suhu di bawah suhu optimum $\left(30^{\circ} \mathrm{C}\right)$ aktivitas lipolitik menurun sampai $90 \%$ dan pada suhu di atas suhu optimum $\left(40^{\circ} \mathrm{C}\right)$ aktivitas lipolitik menurun hingga $70 \%$.

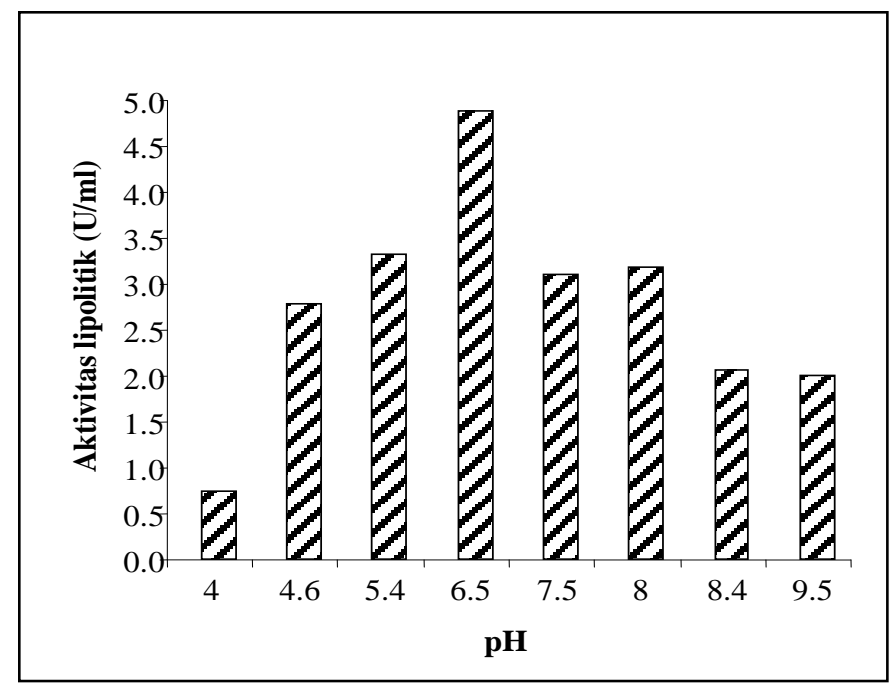

Gambar 4. Aktivitas lipolitik R. microsporus var. oligosporus UICC 550 dengan variasi $\mathrm{pH}$. 


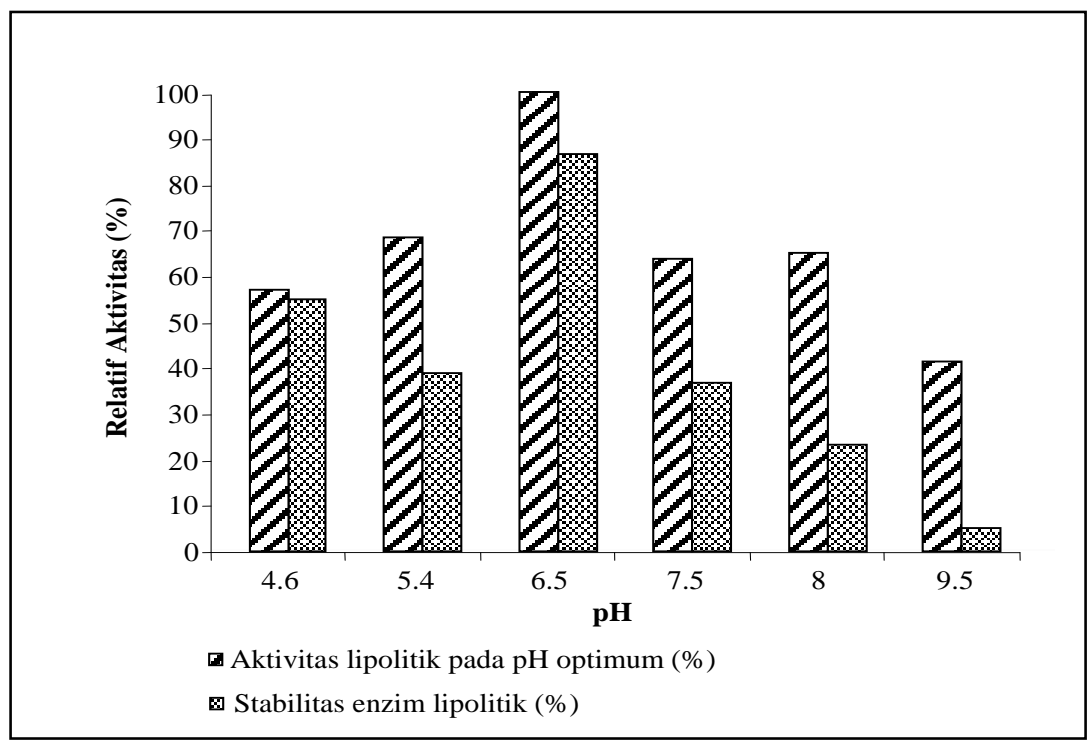

Gambar 5. Pengaruh $\mathrm{pH}$ terhadap prosentase stabilitas enzim lipolitik $R$. microsporus var. oligosporus UICC 550.

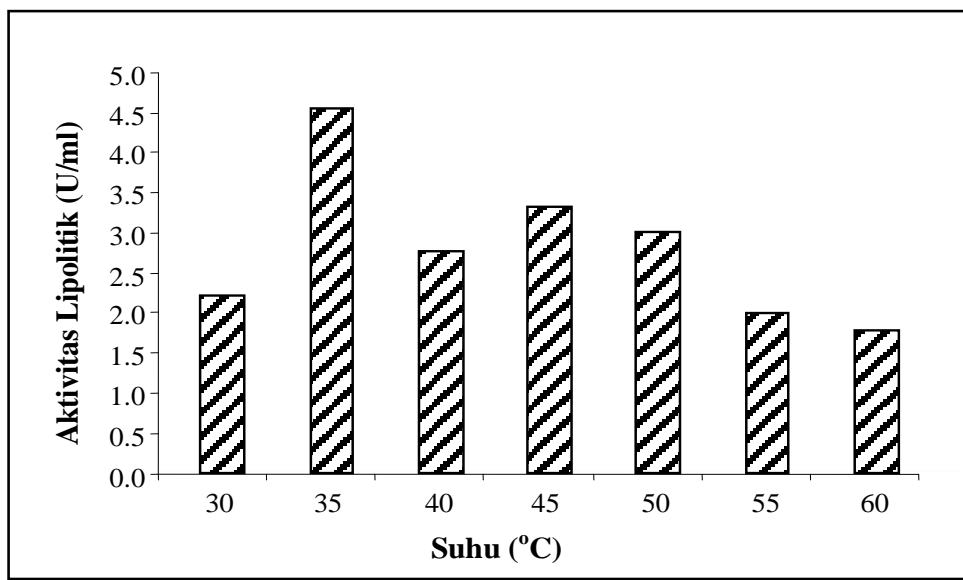

Gambar 6. Aktivitas lipolitik $R$. microsporus var. oligosporus UICC 550 dengan variasi suhu.

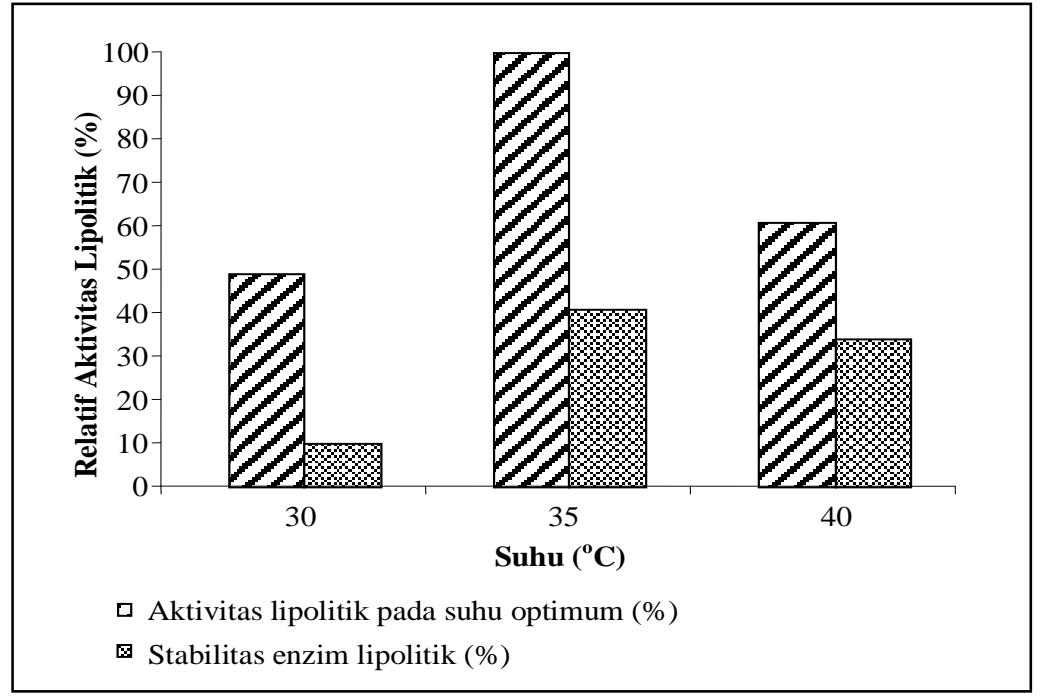

Gambar 7. Pengaruh suhu terhadap prosentase stabilitas enzim lipolitik dari R..microsporus var. oligosporus UICC 550. 
Mucor hiemalis $f$. hiemalis yang diisolasi dari minyak sawit, memproduksi lipase dengan suhu optimum $40^{\circ} \mathrm{C}$ dan $\mathrm{pH}$ optimum 7,0. Lipase $M$. hiemalis stabil ketika diinkubasikan pada skala $\mathrm{pH} 4,0-9,0$ dan suhu $45^{\circ} \mathrm{C}$, selama 15 menit (Hiol et al., 1999), sedangkan lipase yang diproduksi oleh $R$. chinensis memiliki suhu optimum pada $37^{\circ} \mathrm{C}$. Penelitian yang dilakukan oleh Samad et al., (1990) menunjukkan lipase yang bersifat termofilik dari $R$. rhizopodiformis, stabil pada suhu $50^{\circ} \mathrm{C}$ (inkubasi 30 menit) dan $45^{\circ} \mathrm{C}$ (inkubasi 24 jam).

\section{Pengaruh ion-ion divalen terhadap aktivitas enzim}

Gambar 8 menunjukkan penurunan aktivitas lipolitik pada saat enzim diinkubasikan dalam $1 \mathrm{mM} / \mathrm{L}$ ion-ion divalen $\mathrm{Zn}^{2+}, \mathrm{Cu}^{2+}, \mathrm{Mg}^{2+}$ dan $\mathrm{Fe}^{2+}$ selama satu jam. Hal ini menunjukkan bahwa enzim lipase yang dihasilkan oleh $R$. microsporus var. oligosporus UICC 550 tidak memerlukan ion logam yang diuji untuk kofaktor dalam reaksi enzimatiknya.

Aktivitas lipolitik juga dihambat oleh ion $\mathrm{Cu}^{2+}$ dan $\mathrm{Fe}^{2+}$ pada konsentrasi $1 \mathrm{mM}$ pada $M$. hiemalis $f$. hiemalis dan $5 \mathrm{mM}$ untuk $R$. oryzae. Sedangkan $\mathrm{Mn}^{2+}$, justru meningkatkan aktivitas lipase dari M. hiemalis (Sharma et al., 2001). Lipase ekstraselular dari Pseudomonas aeruginosa sangat dihambat oleh $\mathrm{ZnSO}_{4} 1 \mathrm{mM}$ (94\% hambatan). P. pseudoalcaligenes dihambat oleh $\mathrm{Fe}^{3+}$, tapi tidak dihambat oleh ion-ion $\mathrm{Zn}^{2+}, \mathrm{Cu}^{2+}$ dan $\mathrm{Mn}^{2+}$. Sharma et al., (2001) berpendapat bahwa garam-garam logam berat $\left(\mathrm{Fe}^{2+}, \mathrm{Fe}^{3+}, \mathrm{Cu}^{2+}\right.$ dan $\left.\mathrm{Hg}^{2+}\right)$ sangat menghambat lipase karena ion-ion logam tersebut dapat mengubah konformasi enzim.

Pengaruh kekuatan ion dan konstanta dielektrik terhadap kecepatan reaksi enzim kadang-kadang sulit diramalkan, karena sifatsifatnya yang kompleks. Penambahan berbagai jenis garam dapat merubah kekuatan ionik dan konstanta dielektrik larutan tempat enzim bekerja. Perubahan pada kekuatan ion dan konstanta dielektrik larutan enzim, akan mempengaruhi susunan keseluruhan molekul protein atau mengubah derajat ionisasi dan keaktifan substrat, selain itu juga dapat mengubah $\mathrm{pH}$ asam amino yang terlibat pada sisi aktif enzim (Suhartono, 1989).

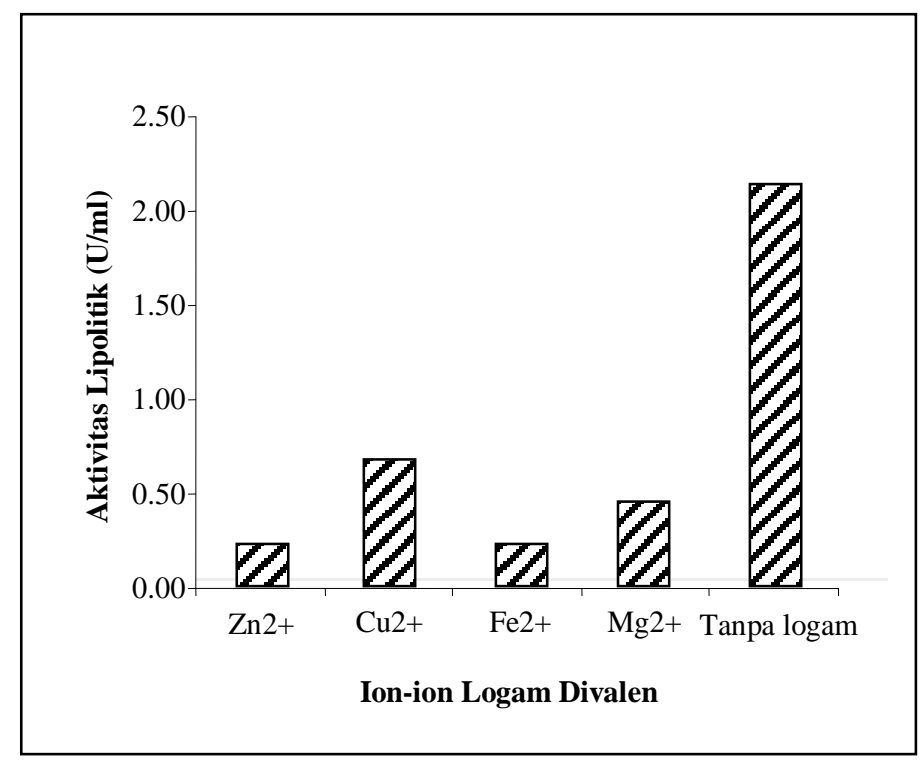

Gambar 8. Pengaruh penambahan ion divalen terhadap aktivitas lipolitik R..microsporus var. oligosporus UICC 550. 


\section{Kesimpulan}

Produktivitas lipase tertinggi pada konsentrasi pepton $5 \%(\mathrm{~b} / \mathrm{v})$ yaitu sebesar 1,33 $\mathrm{U} / \mathrm{ml}$ sebagai sumber nitrogen dan substrat lipid emulsi minyak zaitun 2,5\% (v/v) sebesar $2,72 \mathrm{U} / \mathrm{ml}$ sebagai sumber karbon. Produksi enzim lipolitik maksimum pada waktu inkubasi $20 \mathrm{jam}(1,66 \mathrm{U} / \mathrm{ml})$ pada fase eksponensial dan $56 \mathrm{jam}(2,99 \mathrm{U} / \mathrm{ml})$ pada fase stasioner. Aktivitas lipolitik paling tinggi dicapai pada jam ke 56.

$\mathrm{pH}$ dan suhu optimum enzim lipase pada $\mathrm{pH} 6,5$ dan suhu $35^{\circ} \mathrm{C}$. Enzim stabil pada $\mathrm{pH}$ 6,5 selama 24 jam dan suhu $35^{\circ} \mathrm{C}$ selama satu jam. Aktivitas lipolitik dihambat oleh penambahan $1 \mathrm{mM}$ ion-ion logam divalen $\mathrm{Zn}^{2+}$, $\mathrm{Cu}^{2+}, \mathrm{Mg}^{2+}$, dan $\mathrm{Fe}^{2+}$.

\section{Daftar Pustaka}

Akhtar, M.W., Mirza, A.Q. and Chughtai, M.I.D. 1980. Lipase induction in Mucor hiemalis. Appll. and Environ. Microbiol. 40: 257-263.

Benjamin, S. and Pandey, A. 1996. Optimization of liquid media for lipase production by Candida rugosa. Bioresource Technology 55: 167-170.

Bilgrami, K.S. and Verma, R.N. 1981. Physiology of fungi. Vikas Publishing House, Sahibabat.

Boyer, R. 2002. Concepts in biochemistry. Brooks/Cole. Canada.

Cihangir, N. and Sarikaya, E. 2004. Investigation of lipase production by a new isolate of Aspergillus sp. World J. of Microbiology Biotechnology 20: 193-197.

Colowick, S.P. and Kaplan, N.O. 1955. Methods in Enzymology. Academic Press Inc., Publishers New York.

Davranov, K. and Khalameizer, V.B. 1997. Current state of the study of microbial lipases. Chemistry of Natural Compound 33: 113-126.

Del. Rio, J.L., Serra, P., Valero, F. and Sola, C. 1990. Reaction scheme of lipase production by Candida rugosa growing on olive oil. Biotechnolgn Letters. 12 (11): 825-838.

Druet, Daniele, El., abbadi, N. and Louis, C.C. 1992. Purification and characterization of the extracellular and cell-bound lipases from a Penicillium cyclopium variety. Appl. Microbiol. Biotechnol. 37: 745-749.
Ellibol, M. and Ozer, D. 2002. Response surface analysis of lipase production by freely suspended Rhizopus arrhizus. Process Biochem. 38: 367372.

Hiol, A.M.D., Jonzo, D. and Comeau, L. 1999. Production, purification and characterization of an extracellular lipase from Mucor hiemalis f. hiemalis. Enzyme and Microbial Technology 25: 80-87.

Iwai, M. and Tsujisaka, Y. 1974. The purification and properties of three kind of lipases from Rhizopus delemar. Agr. Biol. Chem. 38 (6): 1241-1247.

Kemarsha, S., Safari, M. and Bisakowski, B. 1998. Characterization of purified lipase fractions from Rhizopus niveus. J. Agric. Food Chem. 46: 4451-4456.

Koblitz, M. and Pastore, M. 2006. Purification and biochemical characterization of an extracellular lipase produced by a new strain of Rhizopus sp. Ciênc. agrotec., Lavras, 30 (3): 494-502.

Kulkarni, N. 2002. Studies on lipase enzyme from Pseudomonas fluorescens NS2W. Thesis. University of Pune, India.

Lakshmi, B.S., Kangueane, P., Abraham, B. and Pennathur, G. 1999. Effect of vegetable oils in the secretion of lipase from Candida rugosa (DSM 2013). Lipids 37 (7): 653-662.

Macris, J.B., Kourentzi, E. and Hatzinikolaou, D.G. 1996. Studies on localization and regulation of lipase production by Aspergillus niger. Procces Biochemistry 31 (8): 807-812.

Maia, M.D.M., Camargo, M.M., Antonio, M., Melo, E.H.M. and Filho, J.L.L. 1999. Production of extracelullar lipase by the phytopathogenic fungus fusarium solani FS1. Revista de Microbiologia. 30: 304-309.

Nahas, E. 1988. Control of lipase production by Rhizopus oligosporus under variuos growth conditions. J. of General Microbiology 134: 227-233.

Pereira-Meirelles, F.V., Rocha-Leilo, M.H.M. and SantAnna Jr, G.L. 2000. Lipase location in Yarrowia lipolytica cells. Biotechnology Letters 22: 71-75.

Pokorny, D., Friedrich, J. and Cimerman, A. 1994. Effect of nutrional factors on lipase biosynthesis by Aspergillus niger. Biotechnology Letters 16 (4): 363-366.

Samad, M., Samad, Y.A., Salleh, A.B., Razak, C.N.A., Ampon, K., Yunus, W.M.Z.W. and Basri, M. 1990. Lipase from a newly isolated thermophilic Rhizopus rhizopodiformis. World J. of Microbio and Biotechno 6: 390-394. 
Sarkar, S., Sreekanth, B., Kant, S., Benerjee, R. and Bhattacharyya, B.C. 1998. Production and optimization of microbial lipase. Bioprocess Engineering 19: 29-32.

Scopes, K.R. 1988. Protein purification principles and practice. Springer-Verlag. New York Inc.

Sharma, R., Chisti, Y. and Banerje, U.C. 2001. Review: Production, purificaton, characterization and application of lipases. Biotechnology Advances 19: 627-662.

Suhartono, M. 1989. Enzim dan Bioteknologi. Departemen Pendidikan dan Kebudayaan. Direktorat Jenderal Pendidikan Tinggi. Pusat Antar Universitas Bioteknologi. Institut Pertanian Bogor.
Taipa, M., Aires-Barros, A. and Cabral, J.M.S. 1992. Purification of lipases. J. of Biotechnology 26: 111-142.

Yasuda, M., Ogino, H., Kiguchi, T., Kotani, T., Takakura, S., Ishibashi, T., Nakashima, T., Fukuda, H. and Ishikawa, H. 1999. Purication and characterization of lipase from Rhizopus chinensis Cells. J. of Bioscience and Bioengineering 88 (5): 571-573.

Yoshida, F., Motai, H. and Eichishima, E. 1968. Effect of lipid materials on the production of lipase by Torulopsis ernobii. Appll. Microbiology 16 (6): 845-847. 